\title{
The Orientation Toward Domestic Labor Questionnaire: Exploring Dual-Earner Wives' Sense of Fairness About Family Work
}

\author{
Alan J. Hawkins \\ Brigham Young University - Provo, hawkinsa@byu.edu \\ Christina M. Marshall \\ Brigham Young University - Provo \\ Sarah M. Allen \\ Brigham Young University - Provo
}

Follow this and additional works at: https://scholarsarchive.byu.edu/facpub

Part of the Other Social and Behavioral Sciences Commons

\section{Original Publication Citation}

Hawkins, A. J., Marshall, C. M., \& Allen, S. M. (1998). The Orientation toward Domestic Labor Questionnaire: Understanding dual-earner wives' sense of fairness about family work. Journal of Family Psychology, 12, 244-258.

\section{BYU ScholarsArchive Citation}

Hawkins, Alan J.; Marshall, Christina M.; and Allen, Sarah M., "The Orientation Toward Domestic Labor Questionnaire: Exploring Dual-Earner Wives' Sense of Fairness About Family Work" (1998). Faculty Publications. 4211.

https://scholarsarchive.byu.edu/facpub/4211

This Peer-Reviewed Article is brought to you for free and open access by BYU ScholarsArchive. It has been accepted for inclusion in Faculty Publications by an authorized administrator of BYU ScholarsArchive. For more information, please contact ellen_amatangelo@byu.edu. 


\title{
The Orientation Toward Domestic Labor Questionnaire: Exploring Dual-Earner Wives' Sense of Fairness About Family Work
}

\author{
Alan J. Hawkins, Christina M. Marshall, and Sarah M. Allen \\ Brigham Young University
}

\begin{abstract}
This study explored the psychometric properties of the Orientation Toward Domestic Labor Questionnaire (ODL-Q) with a sample of 622 dual-earner wives. Adequate internal consistency reliability was obtained for most of the constructs in the ODL-Q. In addition, construct validity for the ODL-Q was provided with multiple regression and discriminant analyses of the constructs' relationships to wives' sense of fairness about family work. The ODL-Q scales accounted for $57 \%$ of the variance in wives' sense of fairness. Effective communication about domestic labor (expressions of appreciation, sympathetic listening, mutual decision making) was by far the most powerful predictor and discriminator of fairness. Further validity was demonstrated in a cluster analysis identifying 3 groups of dual-earner wives suggested by A. Hochschild's (1989) qualitative study of family work. Implications for the construction of gender through domestic labor are discussed.
\end{abstract}

Family researchers recently have been puzzled by consistent empirical findings that although dual-earner wives do two to three times the amount of domestic work their husbands do, less than one third of wives report the division of daily family work as unfair (Blair \& Johnson, 1992; Demo \& Acock, 1993; Lennon \& Rosenfield, 1994; Marshall, Hawkins, \& Meiners, 1994; L. Thompson, 1991). L. Thompson (1991) asserted that "[m]any scholars are stymied by the steadfastness of this seemingly unjust division of labor" (p. 182). Blair and Johnson (1992) admitted they were "deeply puzzled by the seeming irrelevance of gender ideologies for women's perceptions of fairness in the division of household labor" (p. 581).

Early attempts to assess and understand the division of household labor in dual-earner families focused almost exclusively on the

Alan J. Hawkins, Christina M. Marshall, and Sarah M. Allen, Department of Family Sciences and Center for Studies of the Family, Brigham Young University.

Correspondence concerning this article should be addressed to Alan J. Hawkins, Department of Family Sciences and Center for Studies of the Family, 938 Kimball Tower, Brigham Young University, Provo, Utah 84602. Electronic mail may be sent to hawkinsa@byu.edu. dimensions of time and task (Walker \& Woods, 1976). In addition, neoclassic economic perspectives (Becker, 1981) and analyses based on resource theory (Pleck, 1985) discussed the allocation of housework and child care in economic terms, assuming that the division of household labor, like all labor, is rationally determined by the goal of maximizing utility. Sex-role theories were also used by researchers (Pleck, 1985) who based their explanations on the assumption that behaviors and attitudes can be assigned on the basis of what the larger society deems to be proper roles for men and women (Ferree, 1987). The application of traditional economic, exchange, and role theories, however, produced relatively weak understandings of the allocation of domestic labor until researchers began to take the "meaning" or the "symbolic value" of household activities into account (Sanchez \& Kane, 1996).

By the mid-1980s it became increasingly rare to see studies of the division of household labor that did not pay attention in some way to the symbolic value of housework. Theoretical approaches have been reexamined in light of the importance of the meaning of time and task. For example, Pyke and Coltrane (1996) pointed out that human capital theory and social structural 
theory are low in predictive power because they do not take into account how variations in the meaning of housework and paid work affect the allocation of domestic labor. Concepts such as resources and socially structured constraints can be used to analyze the allocation of household tasks only if it is understood that what is a valued resource in one marriage may not be valued in another and that husbands and wives within the same marriage may regularly attribute dissimilar meanings to similar divisions of labor.

In an interesting extension of economic and exchange approaches, Hochschild (1989) discussed the "marital economy of gratitude" (p. 18). She commented that "when couples struggle it is seldom simply over who does what. Far more often it is over the giving and receiving of gratitude" (p. 18). What is viewed as a gift and what is received with appreciation are again a function of the meaning people attach to various chores, attitudes, and behaviors. These meanings and the "gender strategies" for solving problems they create arise out of ongoing marital interaction and not from static societal attitudes (Potuchek, 1992; Pyke \& Coltrane, 1996; Sanchez \& Kane, 1996). Lennon and Rosenfield (1994) contended that power is an important component of these marital dynamics. In an interpretation of Hochschild's findings based on exchange theory, they asserted the following:

Theory and evidence converge to suggest that married women's perceptions of faimess are determined by their power as gauged by their resources and their alternatives to marriage. Having fewer economic resources and trapped by limited options, women are induced to define an objectively unequal situation as just. (p. 50)

Lennon and Rosenfield found, as did Ross, Mirowsky, and Huber (1983), that psychological well-being has far more to do with women's interpretation of their situation than with the actual terms of their employment or their division of household tasks. Women who see the unequal division of housework as unjust are more likely to experience depression. Possibly it is more workable to believe the situation is fair than to acknowledge the unfairness when one doesn't have the power to do much about it. Similarly, Hochschild (1989) said couples create myths about their allocations of domestic labor so the situation can be interpreted as fair.

There are numerous ways people can orient themselves to the division of domestic labor that affect their perceptions of faimess. As Pyke and Coltrane (1996) pointed out, a variety of domestic labor scenarios can result from different mixes of entitlement, obligation, and gratitude. Hochschild (1989) described 10 couples who represented the range of patterns found in the 50+ marriages she studied in the mid-1980s. Traditional, transitional, and egalitarian orientations to domestic labor are evident, as well as some interesting combinations thereof. Hochschild's discussion of each couple highlights the importance of understanding the symbolic values and personal meanings that shape the way the couples orchestrate their work and family lives. Although fairness is not the central issue for many of Hochschild's couples, her descriptions highlight a variety of ways dualearner wives think and feel about apparently unequal situations as they evaluate the faimess of their arrangements.

The most comprehensive conceptual treatment of how unequal situations can be regarded as fair comes from Linda Thompson (1991). Thompson outlined potential mechanisms by which situations are judged fair or unfair, which was the main focus of our study. Thompson encouraged family scholars to use the framework of distributive justice (Deutsch, 1985) as a way of better understanding women's sense of fairness about the gendered division of domestic labor, a recommendation seconded by Blair and Johnson (1992) when they called for "research that is explicitly designed to incorporate measures of all of the factors implicated in Thompson's developing theory of perceptions of gender justice in the division of household labor" (p. 581; see also Sullivan, 1997). The distributive justice framework calls attention to the fact that a strict notion of equity is only one of many values that underlie systems of distributive justice; "need" may be a dominant value of distributive justice in family and other caring systems. That is, when fostering growth and well-being is an important, shared purpose in a group, needs may be of primary concern, and self-sacrifice may be common. Thus, justice can still be an element of caring systems, but it 
operates in different ways compared with systems in which equality is the dominant value.

Major's (1987) work on the distributive justice framework suggested that a sense of fairness and entitlement depends on three factors: outcome values (outcomes that individuals desire from their efforts), comparison referents (processes by which individuals evaluate outcomes), and justifications (appropriateness of the processes or procedures that produce outcomes). L. Thompson (1991) built upon Major's analysis and argued, first, that researchers have been too narrowly focused on only one outcome value-distribution of time and tasks-to explain feelings associated with the division of domestic labor. Researchers should pay particular attention to the interpersonal outcomes women value from domestic labor, such as feeling appreciated or having peace in the home. Second, researchers need to understand the comparisons women make when they evaluate the fairness of family work. Do they compare their husbands' domestic-labor contributions with their own contributions or with the involvement of other men, such as their fathers? In addition, wives sometimes devalue their economic contributions to the family, not viewing themselves as coproviders with their husbands, despite making important financial contributions to their families (Perry-Jenkins \& Crouter, 1990; Potuchek, 1992). Moreover, wives may devalue the attentive, coordinating, "invisible work" of homemaking (DeVault, 1987). L. Thompson (1991) noted that "because family work is embedded in family relations and mingles work and love, women and others do not see it as necessary work" (p. 190). Wives who do not give full credit to the invisible work within the home underestimate their contributions to domestic labor. Third, researchers should take account of the numerous justifications wives may accept to account for the time-and-task disparity in family work. Also, when dual-earner couples feel they have come to a mutual decision about how domestic labor will be accomplished, then wives will be likely to feel things are fair, even if they are doing most of the work. To summarize, L. Thompson (1991) suggested that wives will perceive the allocation of family work as unfair if they lack some valued outcome, if they compare their husbands' contributions to theirs and credit the invisible work embedded in their own domestic labors, and if they are dissatisfied with the procedures by which family work was allocated or reject common justifications for unequal allocation.

Although the increased attention to the symbolic value of domestic labor and to issues of gender and power has been valuable, researchers' abilities to account for the variation in wives' sense of fairness about domestic labor are still modest, and quantitative studies testing the full range of L. Thompson's (1991) ideas have been rare. Work in this area is hampered to date by lack of good instrumentation to measure many of the constructs in Thompson's model. One study (Hawkins, Marshall, \& Meiners, 1995) attempted to test directly Thompson's model of the factors that influence wives' sense of fairness in a sample of 234 dual-earner wives. In this earlier study, we found support for many parts of the model, although there were a few relationships that operated differently from Thompson's hypotheses. The model also demonstrated a substantially greater ability to predict wives' sense of fairness compared with models in other studies. However, strong conclusions were difficult to draw because several of the measures of the constructs in Thompson's model were flawed, exhibiting low reliability, and because of a relatively small sample.

Our purpose in this article, then, is to further our ability to understand dual-earner wives' sense of fairness. The study reported here built on and extended our earlier efforts (Hawkins et al., 1995) by improving measures of the constructs in L. Thompson's (1991) model. Specifically, in this study we improved the reliabilities of some of the weaker measures, added a few constructs that were not included in the earlier study, and examined in more depth the validity of the measures in a larger sample of dual-earner wives by using regression, discriminant, and cluster analyses.

\section{Method}

\section{Sample and Procedure}

Data for this study were collected from adult women residing in five major metropolitan areas in the western United States (Denver, Phoenix, Portland, Sacramento, and Seattle) in 1996. We asked R. L. Polk \& Company to provide us a mailing list of a 
random sample of 1,500 couples in these five metropolitan areas who met the following criteria: (a) intact marriage (not necessarily first), (b) wife employed, (c) husband employed, and (d) at least one child living at home. Of the 1,500 surveys, 19 were returned as undeliverable. With a follow-up postcard and a second mailing encouraging participation in the study (Dillman, 1978), questionnaires were returned from 681 wives, for a response rate of $46 \%$. For the purposes of this study, we excluded 59 wives who were employed less than $15 \mathrm{hr}$ a week, for a resulting sample size of 622 . Wives, on average, were 39 years old $(S D=6.6)$ and had two children under the age of 18 living in the household; $42 \%$ had received a four-year college degree or higher. Wives' median income was $\$ 28,000$, which accounted for $43 \%$ of the family income. The sample was mostly AngloAmerican (87\%). The respondents were employed an average of $39 \mathrm{hr}$ a week $(S D=10.9)$ and reported spending $35 \mathrm{hr}$ a week in domestic labor $(S D=20.7)$, compared with reports of their husbands' $20 \mathrm{hr}$ a week $(S D=15.3) ; 21 \%$ of wives reported this allocation of domestic labor as "unfair" or "very unfair" to them. Both the absolute amounts and reports of fairness are similar to recent studies (Demo \& Acock, 1993; Hawkins et al., 1995).

The limited geographical areas surveyed and the response rate of $46 \%$ left open the possibility that our sample differed from a nationally representative sample on important demographic characteristics. We explored those possible differences by comparing our sample with a sample of dual-earner wives in the United States with intact marriages, working husbands, and at least one child living at home from the 1993-1994 wave of the National Survey of Families and Households (NSFH; Sweet, Bumpass, \& Call, 1988). Wives in the NSFH sample and our sample were both, on average, 39 years old. Likewise, both samples had an average (and mode) of two children in the home. Our sample had received more education than the national sample- $42 \%$ versus $27 \%$ of the wives had obtained a four-year degree or beyond. Not surprisingly, then, wives in our sample had slightly higher incomes than those in the NSFH sample, although they contributed about the same proportion to the family income- $40 \%$ in the NSFH sample compared with $43 \%$ in our sample. Also, wives in our sample worked an average of $4 \mathrm{hr}$ longer than those in the $N S F H$ sample- $39 \mathrm{hr}$ versus $35 \mathrm{hr}$. Our sample was $87 \%$ White compared with $83 \%$ in the NSFH sample. Thus, although we cannot claim to have had a representative sample of dual-earner wives in our study, our sample appears to have been similar to a national sample on important demographic characteristics. However, we had a more educated sample of dual-earner wives than exists in the population.

\section{Measures}

Orientation Toward Domestic Labor Questionnaire scale construction. The Orientation Toward Domestic Labor Questionnaire (ODL-Q) attempts to measure the social-psychological cognitions, attitudes, beliefs, and feelings wives may have about the allocation of family work (housework, child care, and home maintenance). We created items to capture directly the constructs specified in L. Thompson's (1991) model, thus providing a maximum of content validity. Many of the items were taken from our earlier work (Hawkins et al., 1995), but some of the original, less effective items were deleted, and some new items were added.

Studies of family work usually separate housework and child care (and often exclude the latter). We put them together for both conceptual and empirical reasons. Conceptually, distinctions between housework and child care can be fuzzy and often are not clearly made in mothers' minds (Olson, 1979; Ruddick, 1984; L. Thompson, 1991). Empirically, separate items for housework and child care asking about the same content (e.g., fairness) always strongly correlated in our study.

The ODL-Q does not include a global report of gender ideology, which has had mixed results in studies of the allocation of family work. Instead, the ODL-Q focuses on specific cognitions, attitudes, beliefs, and feelings directly related to family work, although notions of proper roles for men and women are certainly embedded in many items. $L$. Thompson (1991) and others (Blair \& Johnson, 1992) have suggested that more specific (as opposed to global) measures like these in the ODL-Q should be more effective in understanding wives' sense of fairness about family work.

Having clearly identified the theoretical constructs from L. Thompson's (1991) model, generated items to measure them, and administered them to a large sample, we evaluated the internal coherence of each construct separately by first specifying one-component solutions in a series of principal components analyses. Thus, we first followed a more theoretically advisable procedure attempting "to confirm the presence of a conceptually distinct subset of scale items" (Sabatelli \& Waldron, 1995, p. 972) with our analyses. As is often the case, some of our items did not relate strongly enough to the others and decreased the internal consistency reliabilities of the scales. When eliminating these items did not seem to diminish the theoretical richness of the construct, we deleted these poorer items to boost the reliability of the scales. The result was a set of 39 items with 12 conceptually distinct subscales (see Table 1) with reasonable alphas (near or above .70). Two constructs that we attempted to measure did not produce 
Table 1

Items, Scales, Cronbach's Alphas, Means, and Standard Deviations for the Orientation Toward Domestic Labor Questionnaire

\begin{tabular}{ll}
\hline Construct and item & Alpha $M$ SD
\end{tabular}

Part A: Valued Outcome scales

Effective Communication About Domestic Labor

I feel appreciated by my spouse for the child care tasks I perform.

I feel appreciated by my spouse for the housework I do.

My family notices the household tasks I do for them.

My husband is a good listener.

My husband listens to me when I talk (complain) about household matters.

My husband and I try to negotiate things together as a couple, including things like household chores.

How housework and child care tasks are divided is an arrangement we decided on together.

Ministering to Family Needs ${ }^{\mathrm{a}}$

I don't think of household chores as housework, I think of them as homemaking.

When I do housework, I feel like I am helping the people I love.

Even if I'm tired, I can usually summon the energy to do household chores because I like to do things for my husband and children.

Most of the time household tasks are just chores to me.

Support of Wage Work ${ }^{\mathrm{a}}$

My husband supports my decision to work for pay.

My husband thinks my working is a good thing.

Responsive to Personal Needs ${ }^{\mathrm{a}}$

When my husband helps around the house and with the kids, it makes me feel like he cares more about me.

It hurts my feelings when my husband doesn't do his fair share around the house.

When husbands help around the house, that is a demonstration of their caring about their wives.

Avoiding Conflict ${ }^{\mathrm{a}}$

If enlisting my spouse's help to do housework and child care is going to lead to conflict, I'd just rather take care of things myself.

If bad feelings start to arise when my husband and I disagree about household chores, I just change the subject.

External Validation of Maternal Role ${ }^{\mathrm{a}}$

If visitors dropped in unexpectedly and my house was a mess, I would be embarrassed.

When my children look well groomed in public, I feel extra proud of them.

I know people make judgments about how good a wife/mother I am based on how well cared for my house and kids are.

I care about what my neighbors, extended family, and friends think about the way I perform my household tasks.

Able to Do It Alla

Other women I know have a harder time than I do balancing their personal needs, their jobs, and their household and family responsibilities.

I am more organized than other women.

It is important to me to be able to feel like I am able to "do it all"; that is, to do my job well and still take care of my family.

\section{Part B: Comparison Referents scales}

Coprovider Orientation ${ }^{\mathrm{a}}$

Providing financially for my family is just as much my responsibility as it is my husband's (even if we don't contribute the same amount of money).

I make an important financial contribution to our family.

Valuing Homemaking ${ }^{\mathrm{b}}$

Homemaking is a legitimate career choice.

It may not be nice to say, but women who devote their energies to homemaking are not making the best use of their skills and talents. 


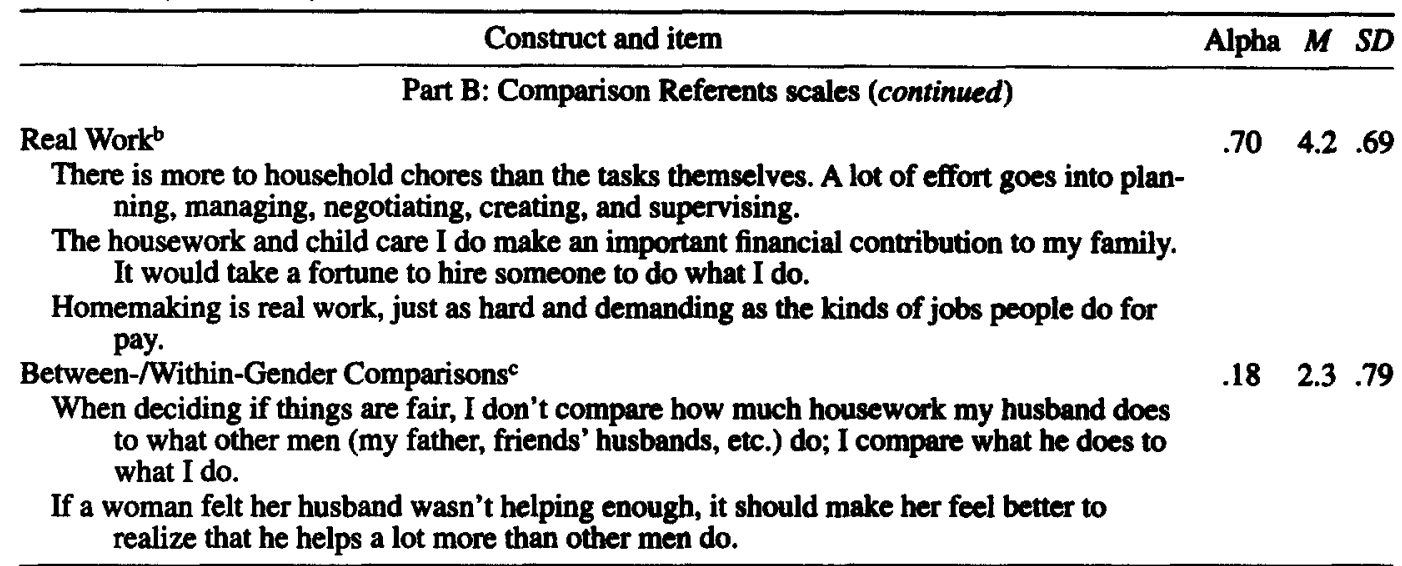

\section{Part C: Justifications scales}

Standards ${ }^{\mathrm{a}}$

I frequently redo some household tasks that my husband has not done well.

It's too hard to teach family members the skills necessary to do the jobs right, so I'd rather do them myself.

My husband doesn't really know how to do a lot of household chores, so it's easier if I just do them.

I like being in charge when it comes to domestic responsibilities.

I have higher standards than my husband for how well cared for the house should be.

Off the Hook

It isn't that men are trying to get out of housework, it's just that they don't know how to do it.

Most women enjoy caring for their homes and men just don't like that stuff.

For a lot of reasons, it's just harder for men than for women to do housework and child care.

Women's Ulimate Accountability ${ }^{\mathrm{a}}$

In the final analysis, I am the one responsible for how well cared for my house is.

In the final analysis, I am the one responsible for how well cared for my children are.

"For the 4-point Likert scale: $1=$ not at all like me; $2=$ a little like me; $3=$ like me; $4=$ very much like me. 'For the 5-point Likert scale: $1=$ strongly disagree; $2=$ disagree; $3=$ neutral; $4=$ agree; $5=$ strongly agree. 'First item is on the 4-point Likert scale; second item is on the 5-point Likert scale.

coherent, reliable scales. These are noted in more detail later.

Performing scale construction in this manner leaves open the possibility that scales will be highly correlated. Thus, to determine whether these 12 scales, constructed independently of each other on conceptual grounds, wonld operate relatively independently of each other empirically, we performed a single principal components analysis with a promax rotation. The results replicated the earlier analyses, with two noteworthy inconsistencies. First, the two items intended to measure the sense that current arrangements for the allocation of domestic labor were discussed and decided on together loaded on the same factor as the five items intended to measure appreciation for domestic labor. This empirical finding suggested to us that expressing appreciation for domestic labor, listening sympathetically to related concerns, and coming to a mutual agreement about who does what were all indicators of a broader construct of effective communication about family work. Thus, because of the conceptual sense of this empirical observation and because the two separate constructs were highly correlated $(r=.58)$, making multivariate analyses challenging, we combined the two scales, Appreciation and Decide Together, into one scale labeled Effective Communication About Domestic Labor.

A second difference that emerged in the rotated factor pattern of the 39 items was that the five items intended to measure the extent to which wives recognize and value the "invisible work" associated with domestic labor were split into two factors, one with two items associated with valuing the home- 
maker role and the other one with three items associated with recognizing that domestic labor is "real work." Although these two concepts are conceptually related, there is also enough distinction in them to warrant accepting the empirical suggestion to separate them, and doing so seemed to add to the conceptual richness of the ODL-Q while not substantially weakening internal scale reliabilities.

Reliabilities for $O D L-Q$ scales. L. Thompson (1991) enumerated several outcomes that dual-earner wives value from the process of family work beyond the equitable distribution of time and tasks. Scales measuring these valued outcomes are presented in Part A of Table 1 along with Cronbach's alphas. The alpha for the Able to Do It All scale was too low (.47). Thus, this scale requires further work before it can be effectively used. The Responsive to Personal Needs scale, with an alpha of .64 , could use improvement but could still be used. The other five scales evidenced adequate reliability with Cronbach's alphas of .70 or higher.

L. Thompson (1991) suggested that dual-earner wives make important comparisons when evaluating the fairness of family work. Scales measuring these comparison referents are presented in Part B of Table 1 along with the Cronbach's alphas. The alpha for the Between-/Within-Gender Comparisons scale (.18) indicates that this construct is poorly measured and cannot be used. The other two scales appear to have adequate reliability with Cronbach's alphas above .70 .

L. Thompson (1991) delineated many possible justifications that dual-earner wives may use that allow them to judge a demonstrably unequal allocation of family work as fair. Scales measuring these justifications are presented in Part $C$ of Table 1 along with the Cronbach's alphas. The alpha for the Off the Hook scale (.67) suggests the scale could still use improvement. The other scales, however, exhibit adequate alphas above 70 .

\section{Construct Validity Findings}

\section{Prediction and Discrimination}

One important way to assess the validity of the ODL- $Q$ is to examine whether the scales are related to wives' sense of fairness in ways consistent with L. Thompson's (1991) analysis on the basis of a distributive justice framework. We approached this task with both multiple regression and discriminant analysis.

We conducted separate analyses for housework and child care and then compared them with the findings from the analyses that combined housework and child care into a single construct of family work. However, the patterns of findings in these two separate analyses were very similar to the findings in the combined analyses. This was not surprising given, for example, that faimess of housework and fairness of child care were highly correlated $(r=.67)$. The other ODL-Q scales were related to these dependent variables in the same directions and with relatively similar magnitudes, although there were some minor variations in which scales were significant predictors and discriminators. Explained variance was somewhat less in these separate models. Because the separate analyses revealed essentially the same pattern of findings as combining housework and child care into a single construct of family work, we chose the more parsimonious presentation, which is consistent with our earlier work (Hawkins et al., 1995; Hawkins, Roberts, Christiansen, \& Marshall, 1994).

Thus, we first regressed the two-item measure of fairness ("Overall, how fair to you do you feel the division of housework is in your family?" and "Overall, how fair to you do you feel the division of child care tasks is in your family?"; Cronbach's alpha $=.80$ ) on the 12 usable composite scales of the ODL-Q presented in Table 1 . In addition, we included in the model a constructed measure of the discrepancy in the time wives spent in family work and the time spent by their husbands ${ }^{1}$ (wives reported both estimates) and a set of demographic variables that could potentially modify the effects of the scales (wives income, education, hours employed, age, and number of children). Results for this assessment of construct validity are presented in Table 2. Eight of the 12 ODL-Q scales were significantly related to wives' reports of fairness. Effective Communication $(\beta=.51)$ produced by far the strongest relationship in the predicted direction with a large effect size of .66 . The strength of this relationship is

\footnotetext{
${ }^{1}$ Our measure asked wives to estimate their hours spent during an average week on family work, including daily housework and child care, less frequent tasks like paying bills, home maintenance and outdoor tasks, and so forth. Similarly, wives also estimated their husbands' average weekly time in family work. A global estimate of time in domestic labor is often ineffective in studies. A discrepancy score, however, creates a distribution that functions much like reports of relative involvement. Direct reports of relative involvement were not available in this data set.
} 
Table 2

Construct Validity Analysis: OLS Regression of Wives' Reports of Fairness About Domestic Labor on ODL-Q Scales and Time Discrepancy in Domestic Labor

\begin{tabular}{lccc}
\hline \multicolumn{1}{c}{ Independent variables } & Standardized $\beta$ & $\begin{array}{c}\text { Effect } \\
\text { size }^{\mathrm{b}}\end{array}$ & $\begin{array}{c}\text { Zero-order } r \\
\text { with fairness }\end{array}$ \\
\hline $\begin{array}{l}\text { Valued outcomes } \\
\text { Effective Communication }\end{array}$ & $.513^{* * *}$ & .66 & $.69^{* * *}$ \\
Ministering to Family Needs & $.063^{*}$ & .09 & $.22^{* * *}$ \\
Support of Wage Work & $.060^{*}$ & .10 & $.13^{* * *}$ \\
Responsive to Personal Needs & $-.070^{*}$ & .09 & $-.20^{* * *}$ \\
Avoiding Conflict & $-.103^{* *}$ & .11 & $-.40^{* * *}$ \\
External Validation of Maternal Role & -.002 & - & $-.18^{* * *}$ \\
Time Discrepancy in Domestic Labor & $-.163^{* * *}$ & .01 & $-.35^{* * *}$ \\
Comparison referents & $-.066^{*}$ & .09 & -.01 \\
Coprovider Orientation & $.065^{*}$ & .07 & -.08 \\
Valuing Homemaking & -.048 & - & .05 \\
Real Work & & & $-.28^{* * *}$ \\
Justifications & .011 & -.05 \\
Standards & $-.191^{* * *}$ & .23 & $-.48^{* * *}$ \\
\hline $\begin{array}{l}\text { Off the Hook } \\
\text { Women's Ultimate Accountability }\end{array}$
\end{tabular}

Note. Adjusted $R^{2}=.57 ; F(18,532)=41.6^{* * *}$. OLS $=$ ordinary least-squares regression; ODL-Q = Orientation Toward Domestic Labor Questionnaire. Dashes indicate that no effect size was computed for a nonsignificant relationship.

Not shown are four demographic variables entered into the model as potential modifiers of the scales: wives' income, education, employment hours, age, and number of children living at home. None of these were statistically significant. bEffect size, in this case, is the unstandardized beta of the independent variable divided by the standard deviation of the dependent variable faimess (1.09). Providing information not only on the statistical significance of a relationship but also on the magnitude of that relationship is encouraged now in the Publication Manual of the American Psychological Association (see B. Thompson, 1996).

${ }^{*} p<.05 . \quad{ }^{* *} p<.01 .{ }^{* * *} p<.001$.

consistent with previous studies (Blair \& Johnson, 1992; Hawkins et al., 1995; Hochschild, 1989); wives who felt their husbands appreciated and listenied to their concerns about their domestic labors and who felt the allocation of labor was a result of a mutual decisionmaking process were more likely to report the division of housework and child care was fair to them. Of note, the predictive power of this variable dwarfs all others in the model. Though other predictors were very modest in their effects, they were statistically reliable. Those who had stronger orientations to domestic labor as a way to minister to family needs $(\beta=.06)$ and who valued the homemaker role $((\beta=.06)$ reported fairer allocations of family work. Also, wives who felt greater support for their wage work $(\beta=.06)$ reported more fairness.

Interestingly, the less wives agreed with the idea that husbands' involvement in domestic labor was a manifestation of care for their wives (Responsive to Personal Needs), the fairer they reported the division of labor to be $(\beta=-.07)$, possibly because they were more willing to make requests of or demands on their husbands rather than hope they will notice some work that needs doing and just do it. Wives' wanting their husbands to pitch in without waiting to be asked was a common frustration in the couples Hochschild (1989) observed. Also, the stronger wives' coprovider orientations were, the less fair they reported the division of domestic labor to be $(\beta=-.07)$, which is consistent with Hochschild's observations.

Two observed relationships, though statistically significant, were opposite what $\mathrm{L}$. Thompson (1991) hypothesized. Wives who tended to accept the justification that they had ultimate 
accountability for housework and child care were less likely to report the division of labor as fair to them $(\beta=-.19)$. Similarly, the more dual-earner wives reported they avoided conflict over domestic labor to preserve harmony in the home, the less fair they reported the division of labor $(\beta=-.10)$. Perhaps wives who were higher on these two scales shouldered a greater proportion of domestic labor. And it was the case that wives who reported a greater time discrepancy in domestic labor between themselves and their husbands reported the allocation of domestic labor as less fair $(\beta=-.16)$. Other scales were not reliable predictors of fairness. ${ }^{2}$ None of the demographic variables was significant.

Certainly of note from this analysis is the substantial proportion of variance explained by these scales. The study by Lennon and Rosenfield (1994) accounted for $18 \%$ of the variance in wives' sense of fairness with variables related to social exchange theory, among others. Blair and Johnson (1992) accounted for about $15 \%$ of the variance in wives' sense of fairness with variables such as appreciation and gender-role ideology, among others, and recommended that researchers use more of the constructs suggested by L. Thompson's (1991) model. Sanchez and Kane (1996) explained $12 \%$ of the variance in wives' reports of fairness from an array of variables available in the $N S F H$. We were able to account for more than half (adjusted $R^{2}=.57$ ) of the variance in wives' sense of fairness with the scales of the ODL-Q. This reinforces the value of exploring the kinds of constructs used in this study to understand faimess.

We used a second analytic approach to construct validity with discriminant analysis, which told a story similar to the regression analysis. Using the same set of variables as discriminators of whether wives said the division of domestic labor was fair (or very fair), unfair (or very unfair), or in-between, we found that Effective Communication About Domestic Labor was by far the strongest discriminator (partial $R^{2}=.44$ ). The other scales that significantly predicted wives' sense of fairness in the regression analysis also were significant discriminators, except for Support for Wage Work. Use of these discriminators correctly classified $79 \%$ of cases in the "unfair" category, and $80 \%$ of cases in the "fair" category (a chance correct classification was $33 \%$ ). Only $4 \%$ of wives who reported the division of labor as "unfair" were incorrectly classified as "fair," and only $3 \%$ of those who said things were "fair" were incorrectly classified as "unfair."

It is also illuminating to demonstrate graphically the relationship between some of the ODL-Q scales and wives' reports of fairness. In Figure 1, we illustrate the increasing (or decreasing) percentages of wives who reported the division of labor as fair (or unfair) according to their quartile position on the distribution of Effective Communication About Domestic Labor, the strongest predictor and discriminator of fairness. When wives were in the lowest quartile (Q1) of scores for Effective Communication, only $5 \%$ said that the division of labor was fair, and more than $57 \%$ said things were unfair. In contrast, when wives were in the highest quartile (Q4) of scores for Effective Communication, then $58 \%$ said that the division of labor was fair and only $2 \%$ said things were unfair. The implication, then, is that if couples decide on the allocation of domestic labor together and wives feel appreciated for their family work, then it is highly unlikely that they feel the division of labor is unfair to them.

\section{Clusters of Dual-Earner Wives}

A final and critical set of validity-related analyses explored whether the ODL-Q scales could produce meaningful classifications of dual-earner wives with respect to patterns of thinking about domestic labor, and subsequently, whether these groups would differ in terms of their sense of fairness about family work. Jain, Belsky, and Crnic (1996) argued that researchers focus too often on isolated behaviors and attitudes rather than on individuals who come packaged with a set of connected behaviors and attitudes. Magnusson (1995) recommended that researchers give more attention to the organization and patterning of behaviors and attitudes within individuals. Consequently, we used cluster analysis-a multivariate technique for grouping individuals - to detect groups of dual-earner wives in terms of their orientations toward family work. First, the clustering variables were standardized. We used the Statistical Analysis System (SAS) FASTCLUS procedure

\footnotetext{
${ }^{2}$ Analyses not shown were checked for possible curvilinear effects, but none was found.
} 


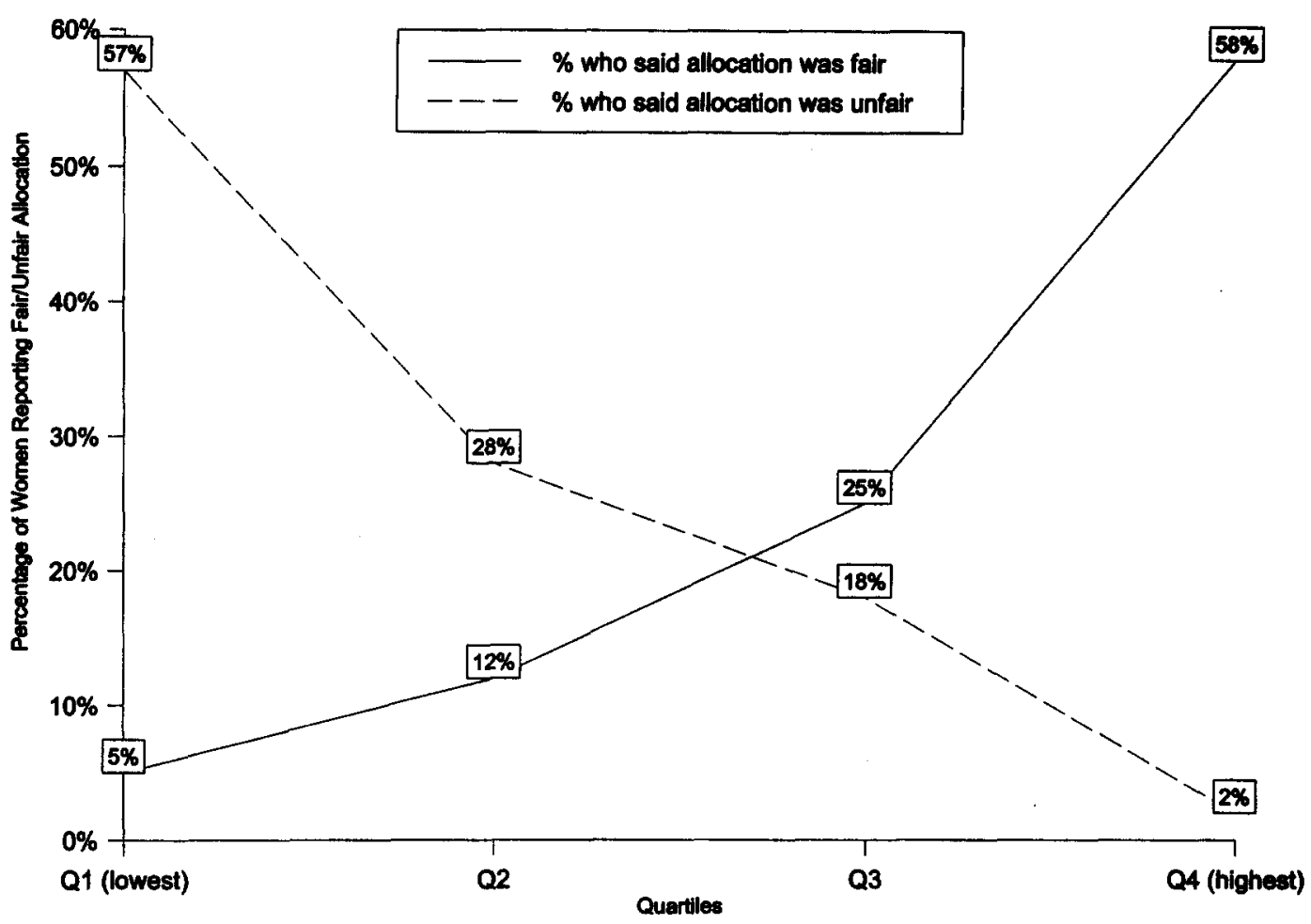

Figure 1. Percentages of wives who reported the division of labor as fair or unfair by quartiles of the distribution for effective communication about domestic labor.

that uses Euclidean distance measures and the nearest centroid method (Anderberg, 1973).

Determining the number of clusters in an analysis is challenging, especially in exploratory analyses with more than a handful of clustering variables. First, we decided a solution with fewer clusters that captured more general categories of dual-earner wives that were readily interpreted would be preferable to a manycluster solution with finer distinctions that would be more difficult to understand. In addition, we sought some conceptual guidance from Hochschild's (1989) influential study of dual-earner families. Although there were unique features in each of the couples Hochschild observed and interviewed, there seemed to be three broad types. First, there was a group of dual-earner wives who had worked out relatively egalitarian allocations of domestic labor with their husbands (e.g., "Carol Alston" or "Adrienne Sherman"). Second, there was a group of wives ideologically committed to egalitarian lives and domestic equality, but who struggled with their husbands in various ways to implement this ideal and were frustrated as a result (e.g., "Nancy Holt" or "Jessica Stein"). A third group was identified by a challenging mixture of relatively traditional values in terms of family roles but modern lifestyles (e.g., "Carmen Delacorte" or "Nina Tanagawa"). We were able, at least to some extent, to identify these three broad groupings of dual-earner wives in our sample (see Tables 3 and 4).

Relational egalitarians. The largest cluster in our analysis is characterized by a group of wives who were highest in Ministering to Family, or an orientation toward domestic labor as a way to serve and help family members, and they valued the homemaking role highly. In addition, they had the highest scores on Effective Communication About Domestic Labor (i.e., expressed appreciation, listening to concerns, and deciding together). Also, this group reported a high level of support from their husbands for their paid work outside the home. This group had the lowest scores in Avoiding 
Conflict, Women's Ultimate Accountability, and Standards. They also had the least discrepancy in husbands' and wives' time in family workabout $8 \mathrm{hr}$. (Husbands in all groups were employed significantly more hours than their wives.) Thus, this group of dual-earner wives, which composed nearly half of our sample (48\%), appeared to enjoy positive, relatively egalitarian relationships, and interestingly, valued the importance and relational nature of domestic work. Although most studies have stressed the egalitarian allocation issue, it is worth noting that our study suggests that achieving this goes hand-in-hand with a positive outlook on the value of homemaking rather than a rejection of it, a possibility suggested by Ahlander and Bahr (1995). Thus, we refer to this cluster of wives as relational egalitarians.

Coproviders. A second cluster could be called coproviders (Hood, 1986; Perry-Jenkins $\&$ Crouter, 1990). These are women who had the strongest attachments to their identities as employees, who received strong support for their wage work, and who held attitudes suggesting they worked hard to create egalitarian arrangements in the home, but with less success than the relational egalitarians. The discrepancy in husbands' and wives' time in domestic labor was about $12 \mathrm{hr}$ for this group. This cluster had the lowest scores on scales suggesting low identification with the homemaking role. Also, as a group, these couples were less effective in their communication behaviors about domestic labor. It appears this second group, about $10 \%$ of our sample, focused directly on domestic equality but was less likely to achieve it than the first group.

Transitional second shifters. The third cluster matches well those wives described by Hochschild (1989) as having a transitional gender ideology. These are women who are employed outside the home but who carry with them a set of relatively traditional gender-role values and attitudes. This group constituted about $40 \%$ of our sample and fit well the label transitional second shifters. They are highest in (a) an attitude that a husband's involvement is a sign that he cares about his wife's personal needs, (b) a pattern of wives' doing domestic labor themselves if it helps to avoid family conflict, (c) a sense that others will judge them by how

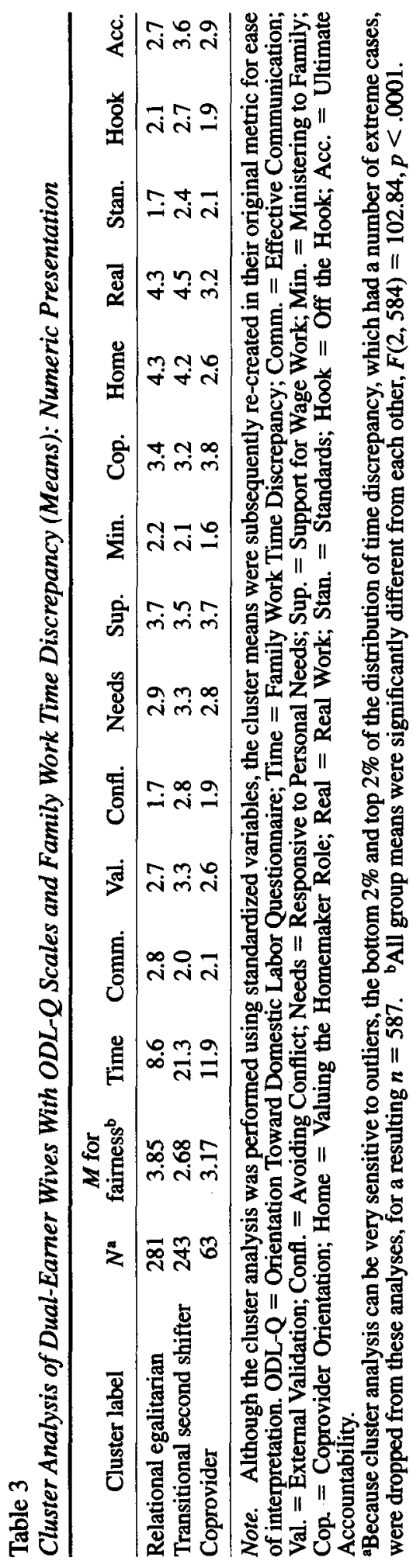


Table 4

Cluster Analysis of Dual-Earner Wives With $O D L-Q$ Scales and Family Work Time Discrepancy: Text Presentation

\begin{tabular}{|c|c|c|}
\hline Cluster label & Highest score & Lowest score \\
\hline Relational egalitarian & $\begin{array}{l}\text { Ministering to Family } \\
\text { Effective Communication about Domestic } \\
\text { Labor } \\
\text { Support for Wage Work } \\
\text { Valuing Homemaking }\end{array}$ & $\begin{array}{l}\text { Avoiding Conflict } \\
\text { Women's Ultimate Accountability } \\
\text { Standards } \\
\text { Family Work Time Discrepancy }\end{array}$ \\
\hline $\begin{array}{l}\text { Transitional second } \\
\text { shifter }\end{array}$ & $\begin{array}{l}\text { Responsive to Personal Needs } \\
\text { Avoiding Conflict } \\
\text { External Validation of Maternal Role } \\
\text { Real Work } \\
\text { Off the Hook } \\
\text { Standards } \\
\text { Ultimate Accountability } \\
\text { Family Work Time Discrepancy }\end{array}$ & $\begin{array}{l}\text { Effective Communication about Domestic } \\
\text { Labor } \\
\text { Coprovider Orientation } \\
\text { Support for Wage Work }\end{array}$ \\
\hline Coprovider & $\begin{array}{l}\text { Coprovider Orientation } \\
\text { Support for Wage Work }\end{array}$ & $\begin{array}{l}\text { Ministering to Family } \\
\text { Valuing Homemaking } \\
\text { Real Work } \\
\text { Responsive to Personal Needs } \\
\text { External Validation of Maternal Role } \\
\text { Off the Hook }\end{array}$ \\
\hline
\end{tabular}

Note. ODL-Q $=$ Orientation Toward Domestic Labor Questionnaire.

nice their home and children look, (d) a value that domestic labor is "real work," (e) an inclination to let husbands off the hook because they don't enjoy doing or know how to do domestic work, (f) a commitment to high standards for housework and child care, and (g) a feeling that wives, not husbands, are held ultimately accountable for domestic labor. They also value the homemaking role highly. Given this confluence of cognitions, it is not surprising that these wives have the greatest discrepancy between their time and their husbands' time in domestic labor, about $21 \mathrm{hr}$. Moreover, these wives are lowest in (a) effective communication patterns about domestic labor, (b) a commitment to being a coprovider, and (c) receiving support for their wage work. These women appear to carry a set of traditional gender-role attitudes that does not fit well their situations as paid employees.

To determine the reliability of this cluster solution, we randomly divided the sample in half and attempted to replicate the same three-cluster solution on each half of the sample, as recommended by Aldenderfer and Blashfield (1984) and B. Thompson (1996). Despite only modest separation of the clusters, there was clear replication of the transitional second shifter group in both half samples. The copro- vider and relational egalitarian clusters did not replicate as clearly, however, although there were many similarities to the full-sample solution. Accordingly, we recommend some caution; further replication of this cluster solution is needed with different samples before we can be confident that these groups represent reliable classifications.

Finally, we performed a one-way analysis of variance on wives' sense of fairness about family work using this classification of dualearner wives. On the basis of our earlier regression and discriminant analyses that revealed the stronger predictors and discriminators of fairness, we expected that relational egalitarians would be highest in faimess, transitional second shifters would be lowest, and coproviders would be in the middle. These expectations were confirmed (see Table 3 ), and the differences were all statistically significant. This is further evidence, then, for the validity the ODL-Q scales.

\section{Discussion}

This study suggests that most of L. Thompson's (1991) constructs that influence dualearner wives' sense of faimess about family 
work can be measured reliably by the ODL-Q. In addition, some construct validity for the instrument is suggested by the predictive and discriminatory power of the scales of the ODL-Q in terms of wives' sense of fairness and their ability to produce a conceptually meaningful classification of dual-earner wives. Admittedly, some of the constructs were not related to fairness in multivariate analyses, and a few were related but not in the ways Thompson initially hypothesized. This may indicate, however, that the model needs modest refinement. In addition, there are still a few important constructs not adequately measured by this version of the ODL-Q that need to be improved (e.g., withingender comparisons). Also, it will be important to include dual-earner men's perspectives in future studies. Nevertheless, our research suggests that scholars will benefit from giving more attention to the kinds of constructs assessed in this study, particularly now that an instrument with demonstrated reliability and validity is available to do so. Of course, this is only one study; replication of results on different samples using the ODL-Q is the strongest form of reliability and validity.

Beyond the methodological contributions of this study, there are some substantive issues worth noting. First, we think this research helps to solve the puzzle mentioned in the introduction: "the seeming irrelevance of gender ideologies for women's perceptions of fairness in the division of household labor" (Blair \& Johnson, 1992, p. 581). Gender ideology is usually operationalized in terms of broad, normative roles for men and women in society. Note that the ODL-Q scales are not about abstract notions of gender roles that are influenced by shifting cultural winds in a media-saturated society. Rather, the ODL-Q scales attempt to tap ideas and feelings deeply embedded in the proximate, day-to-day thoughts and actions about domestic labor that shape how these mothers construct gender. As Hochschild (1989) argued, gender ideologies are intimately linked to women's sense of faimess only when we go beneath the surface to the "deep ideologies" that women and men hold and the "gender strategies" they use to operationalize them. The ODL-Q constructs are effective at tapping these deep ideologies, the concrete, cognitive connections to the prosaic, daily work of raising children and maintaining a home and family - the primary activities through which women (and men) construct their gender ideologies (Coltrane, 1996; Pyke \& Coltrane, 1996).

And in another way, this study supports the notion that family work is about more than getting tasks done; it is also a process by which we explore meanings of gender. Our research confirms the importance L. Thompson (1991) placed on valued outcomes other than an equitable distribution of time and tasks in domestic labor. That is, there are important personal, interpersonal, and familial outcomes dual-earner wives value from their family work, such as feeling appreciated and serving family members by maternal ministrations. As noted earlier, previous studies have struggled to account for much variance in wives' sense of fairness. Our study, however, which included a wide array of possible valued outcomes, was able to account for more than half the variance. Not surprising, most of that added variance comes from communication behaviors around the division of domestic labor that may be especially critical to the dual-earner structure and lifestyle. A construct that includes expressions of appreciation from husbands to wives, listening sympathetically to wives' concerns about family work, and mutual decision making about the allocation of tasks was by far the strongest determinant of wives' sense of fairness. Yet beyond the specific behavioral manifestations in this construct, the symbolic importance of these behaviors should be stressed. They show respect for, understanding of, and interest in the hard work of domestic labor, a labor that women in our study did more of than their husbands but still valued highly, and it is unlikely that these behaviors are part of a manipulative strategy used by husbands to get out of domestic labor. In our previous study (Hawkins et al., 1995) and this one, we observed healthy associations between these constructs and greater paternal involvement in family work. Hence, although expressions of appreciation, sympathetic listening, and mutual decision making themselves certainly contribute directly to dual-earner wives' sense of fairness, we suspect the respect for family work underlying husbands' effective communication about domestic labor, as well as the sense of mutuality 
generated when both husbands and wives value domestic labor, also make strong contributions to wives' satisfaction with their current constructions of gender.

Finally, on an applied level, family life educators and marriage and family therapists can find value in use of the ODL-Q. Practitioners working with dual-earner couples struggling with the division of family work may use this instrument with their clients as both an educational and a diagnostic tool. Although the ODL-Q has not yet been normed on a representative sample of dual-earner wives, the means and standard deviations provided in this study with a large sample provide an initial way to assess wives' scores on each construct in comparison with other middle-class women. Also, the constructs measured by the ODL-Q, such as effective communication about domestic labor, having ultimate accountability for domestic labor, and responsiveness to personal needs, are important in understanding how wives assess the fairness of family work and are open to educational and therapeutic interventions that can help dual-earner couples (Hawkins et al., 1994; Rasmussen, Hawkins, \& Schwab, 1996).

\section{References}

Ahlander, N. R., \& Bahr, K. S. (1995). Beyond drudgery, power and equity: Toward an expanded disclosure on the moral dimensions of housework and families. Journal of Marriage and the Family, $57,54-68$.

Aldenderfer, M. S., \& Blashfield, R. K. (1984). Cluster analysis. Beverly Hills, CA: Sage.

Anderberg, M. (1973). Cluster analysis for applications. New York: Academic Press.

Becker, G. (1981). A treatise on the family. Cambridge, MA: Harvard University.

Blair, S. L., \& Johnson, M. P. (1992). Wives' perceptions of the fairness of the division of household labor: The intersection of housework and ideology. Journal of Marriage and the Family, 54, 570-581.

Coltrane, S. (1996). Family man. New York: Oxford University Press.

Demo, D. H., \& Acock, A. C. (1993). Family diversity and the division of domestic labor: How much have things really changed? Family Relations, 42, 323-331.

Deutsch, M. (1985). Distributive justice: A socialpsychological perspective. New Haven, CT: Yale University.

DeVault, M. L. (1987). Doing housework: Feeding and family life. In N. Gerstel \& H. E. Gross (Eds.), Families and work (pp. 178-191). Philadelphia: Temple University Press.

Dillman, D. A. (1978). Mail and telephone surveys: The total design method. New York: Wiley.

Ferree, M. M. (1987). Family and job for workingclass women: Gender and class systems seen from below. In N. Gerstel \& H. Engel Gross (Eds.), Families and work (pp. 289-301). Philadelphia: Temple University Press.

Hawkins, A. J., Marshall, C. M., \& Meiners, K. M. (1995). Exploring wives' sense of faimess about family work: An initial test of the distributive justice framework. Journal of Family Issues, 16, 693-721. Hawkins, A. J., Roberts, T., Christiansen, S. L., \& Marshall, C. M. (1994). An evaluation of a program to help dual-earner couples share the second shift. Family Relations, 43, 213-220.

Hochschild, A. (1989). The second shift: Working parents and the revolution at home. New York: Viking Press.

Hood, J. C. (1986). The provider role: Its meaning and measurement. Journal of Marriage and the Family, 48, 349-359.

Jain, A., Belsky, J., \& Crnic, K. (1996). Beyond fathering behaviors: Types of dads. Journal of Family Psychology, 10, 431-442.

Lennon, M. C., \& Rosenfield, S. (1994). Relative fairness and the division of housework: The importance of options. American Journal of Sociology, 100, 506-531.

Magnusson, D. (1995). Individual development: A holistic integrated model. In P. Moen, G. H. Elder, \& K. Luscher (Eds.), Linking lives and contexts: Perspectives on the ecology of human development (pp. 19-60). Washington, DC: American Psychological Association.

Major, B. (1987). Gender, justice, and the psychology of entitlement. In P. Shaver \& C. Hendrick (Eds.) Sex and gender (pp. 124-148). Newbury Park, CA: Sage.

Marshall, C. M., Hawkins, A. J., \& Meiners, K. M. (1994, November). Digging deeper: Unasked questions about the division of family work in dual earner households. Poster presented at the National Council on Family Relations Annual Conference, Minneapolis, MN.

Olson, J. T. (1979). Role conflict between housework and child care. Journal of Work and Occupations, 6 430-456.

Perry-Jenkins, M., \& Crouter, A. C. (1990). Men's provider-role attitudes: Implications for household work and marital satisfaction. Journal of Family Issues, 11, 136-156.

Pleck, J. H. (1985). Working wivestworking husbands. Beverly Hills, CA: Sage.

Potuchek, J. L. (1992). Employed wives' orientations 
to breadwinning: A gender theory analysis. Journal of Marriage and the Family, 54, 548-558.

Pyke, K., \& Coltrane, S. (1996). Entitlement, obligation, and gratitude in family work. Journal of Family Issues, 17, 60-82.

Rasmussen, K. S., Hawkins, A. J., \& Schwab, K. P. (1996). Increasing husbands'.involvement in domestic labor: Issues for therapists. Contemporary Family Therapy, 18, 209-222.

Ross, C. E., Mirowsky, J., \& Huber, J. (1983). Dividing work, sharing work, and in-between: Marriage patterns and depression. American Sociological Review, 48, 809-823.

Ruddick, S. (1984). Maternal thinking. In J. Trebilcot (Ed.), Mothering: Essays in feminist theory (pp. 213-230). Totowa, NJ: Rowman \& Allanheld.

Sabatelli, R. M., \& Waldron, R. J. (1995). Measurement issues in the assessment of the experiences of parenthood. Journal of Marriage and the Family, 57, 969-980.

Sanchez, L., \& Kane, E. W. (1996). Women's and men's constructions of perceptions of housework faimess. Journal of Family Issues, 17, 358-387.
Sullivan, O. (1997). The division of housework among "remarried" couples. Journal of Family Issues, 18, 205-223.

Sweet, J. A., Bumpass, L. L., \& Call, V. R. A. (1988). The design and content of the National Survey of Families and Households (Working Paper No. NSFH-1). Madison, WI: University of Wisconsin, Center for Demography and Ecology.

Thompson, B. (1996). AERA editorial policies regarding statistical significance testing: Three suggested reforms. Educational Researcher, 25, 26-30.

Thompson, L. (1991). Family work: Women's sense of fairness. Journal of Family Issues, 12, 181-196.

Walker, K. E., \& Woods, M. E. (1976). Time use: A measure of household production of family goods and services. Washington, DC: American Home Economics Association.

Received March 31, 1997

Revision received June 22, 1997 Accepted November 28, 1997 